\title{
Editorial
}

Neuro-

\section{"A Battle You Would Never Choose to Fight": The Management of Neurodegenerative Diseases as a Societal Challenge}

\author{
Jonathan Steffen \\ Jonathan Steffen Limited, Cambridge, UK
}

\author{
"Maud Shade was eighty when a sudden hush \\ Fell on her life. We saw the angry flush \\ And torsion of paralysis assail \\ Her noble cheek. We moved her to Pinedale, \\ Famed for its sanitarium. There she'd sit \\ In the glassed sun and watch the fly that lit \\ Upon her dress and then upon her wrist. \\ Her mind kept fading in the growing mist. \\ She still could speak. She paused, and groped, and found \\ What seemed at first a serviceable sound, \\ But from adjacent cells impostors took \\ The place of words she needed, and her look \\ Spelt imploration as she fought in vain \\ To reason with the monsters in her brain." \\ Vladimir Nabokov, Pale Fire [1]
}

\section{“Sting like a Bee"}

What do the singers Glen Campbell and Perry Como have in common? Or the actors Charlton Heston and Rita Hayworth? Or, to mix things up a bit, the boxer Sugar Ray Robinson and the composer Aaron Copland? The answer is that they all suffered from Alzheimer's disease [2]. One could perform the same exercise with Parkinson's disease: the singer Neil Diamond ended a 50-year career of touring in January 2018 as a result of Parkinson's disease [3], and other famous sufferers from the condition include the actor Alan Alda, the comedian Billy Connolly, the singer Linda Ronstadt, and, perhaps most famously of all, the boxer Muhammad Ali. How can the beautiful young man whose motto was "Float like a butterfly, sting like a bee" have fallen victim to such a cruel sting?

What is poignant about these examples is not just that they remind us how neurodegenerative diseases strike down the rich and famous as remorselessly as they do the impoverished and obscure. It is also the fact that such lists exist, and that the victims of these conditions are also in many cases champions - fighting against the dying of their own light but also on behalf of the unknown millions who either have, or will one day develop, the neurodegenerative disease from which they themselves suffer.

The scale of the problem is breathtaking. According to the United States Alzheimer's Association, deaths attributable to heart disease in the US fell by $11 \%$ between 2000 and 2015, while deaths from Alzheimer's disease increased during the same period by a staggering $123 \%$ [4]. According to the same source, one in three US senior citizens dies from Alzheimer's or another form of dementia (Fig. 1), which is the sixth leading cause of death in the country. In 2018, 61.1 million Americans provided unpaid care for people with Alzheimer's or other forms of dementia, collectively making available an estimated 18.4 billion h of care, valued at USD 232 billion. And the global prevalence of dementia in all its forms is predicted to quadruple by the year 2050 [5].

\section{KARGER}

(c) 2019 S. Karger AG, Basel

E-Mail karger@karger.com

www.karger.com/ndd
Jonathan Steffen

Jonathan Steffen Limited

153 St Neots Road

Hardwick, Cambridge CB23 7QJ (UK)

E-Mail jonathan.steffen@ corporatestory.co.uk 


\section{The Burden of Neurodegenerative Disease}

It is one of the supreme ironies of progress that the scientific achievements that have dramatically increased life expectancy for so many millions in the course of a few short decades have also meant that millions of people are more exposed than ever before to the possibility of developing a neurodegenerative disease. This trend of course does not just affect the individual patient. It has a significant impact on healthcare systems, which are already struggling under the burden of rising population growth, transformational new technologies, and steadily rising expectations on the part of patients. It also has a major, and not infrequently life-changing, impact on nonprofessionals - usually, close relatives who are not trained in dealing with dementia and who already have their own lives to live and their own burdens to bear.

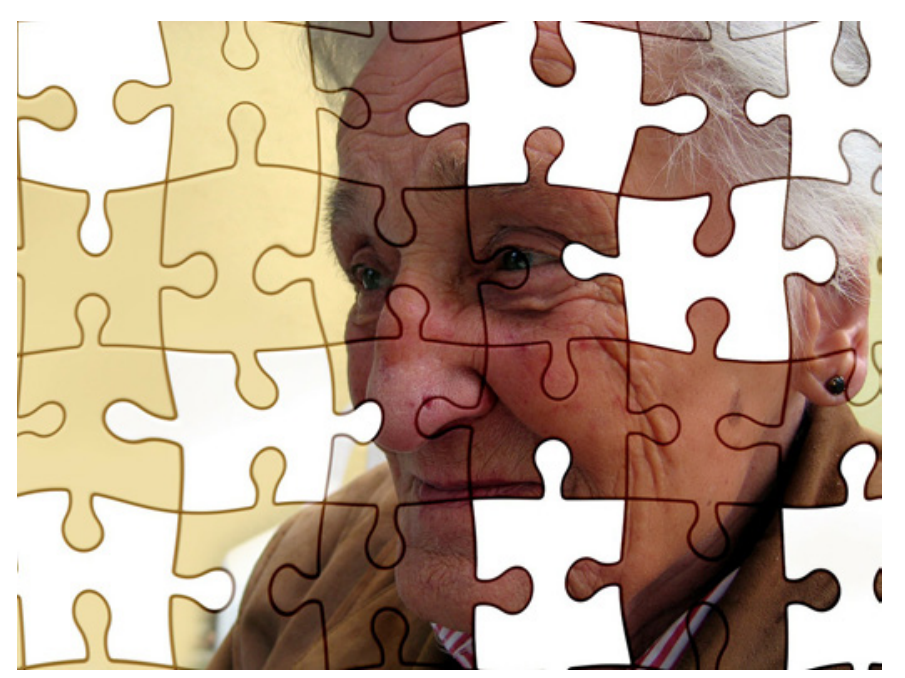

Fig. 1. One in three US senior citizens dies from Alzheimer's disease or another form of dementia.
It seems that, while modern medicine, supported by public health programming, has allowed people's bodies to live longer, it has not yet found effective ways to help their minds live longer. Substantial progress has been made over the past few decades in understanding Alzheimer's disease, for example, opening up the possibility of new avenues for genetic testing, prevention, and treatment [5], but many of these solutions still lie in the future. The result is that hospitals, which were never conceived as places for the management of age-related neurodegenerative diseases, are currently struggling to cope with the new demands. So too are social care professionals. And the relatives of those with neurodegenerative diseases are inevitably the hardest hit. They are seeing their loved ones - usually their parents - literally taken away from them day by day.

\section{“How will a Society Cope?"}

Terry Pratchett - best-selling author of the Discworld novels - who died in February 2015 of posterior cortical atrophy (PCA), a rare form of early-onset dementia - articulated the problem with stark simplicity: "The baby boomers are getting older, and will stay older for longer. And they will run right into the dementia firing range. How will a society cope? Especially a society that can't so readily rely on those stable family relationships that traditionally provided the backbone [6]."

Not surprisingly, the plethora of websites dedicated to victims of dementia and their carers is mirrored by a wide range of recently published full-length books, from Wendy Mitchell's [7] account of her own experience of Alzheimer's disease and Terry Rummins' [8] chronicle of her struggles with Parkinson's to books aimed at those

Fig. 2. When dementia strikes, there is always more than one sufferer.

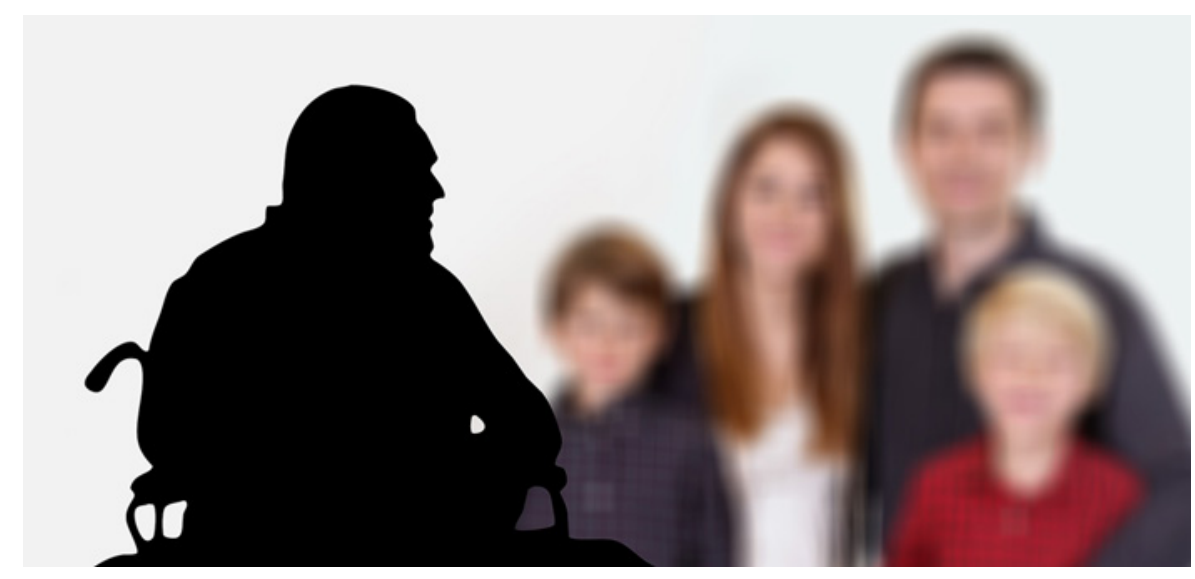


who care for people with neurodegenerative diseases [913]. None of the extensive writings on the subject suggest that the experience is anything but challenging, for the patient as for the carer - and the many websites on the internet with quotes about coping with neurodegenerative diseases give an index of the scale of the suffering caused by these conditions, from the inspirational "We remember their love when they can no longer remember" [14] to the resigned "Dementia is a battle you would never choose to fight ... Because you will never win [15]." Judy Cornish [16] puts her finger on one of the key challenges of supporting people with dementia: "Offering care means being a companion, not a superior. It doesn't matter whether the person we are caring for is experiencing cancer, the flu, dementia, or grief. If you are a doctor or surgeon, your expertise and knowledge comes from a superior position. But when our role is to be providers of care, we should be there as equals."

\section{Fighting Monsters}

This observation is a deep one, because it locates the coping mechanism not within the framework of medical science (drug-based therapies, physical and mental gymnastics, improved diets) but rather within the framework of perception, making it a moral rather than a practical response. While hoping for a new generation of medicines and other therapeutic approaches that will delay the onset of neurodegenerative diseases and diminish their effect, society needs to find better ways of caring for patients whose lives are compromised by them. This can only start to happen if society as a whole realizes that neurodegenerative disease, a kind of death-before-death, is something that can happen to all of us, either directly or vicariously. Neurodegenerative diseases do not just "happen" to a single individual. They affect that individual's spouse or partner, children, grandchildren, friends, neighbors, and colleagues. In the quotation from Nabokov's [1] novel Pale Fire, which prefaces this essay, there is more than one sufferer (Fig. 2). Maude Shade is fighting in vain to reason with the monsters in her brain; but the people witnessing that unequal struggle also need all the help society can provide.

\section{Disclosure Statement}

The author declares no conflicts of interest.

\section{Funding Sources} lishers.

\section{References}

1 Nabokov V. Pale Fire. New York: G.P. Putnam's Sons; 1962.

2 https://www.aplaceformom.com/blog/10-celebrities-with-alzheimers-disease/. Accessed 18 February 2019.

3 https://www.everydayhealth.com/parkinsons-disease-pictures/famous-people-withparkinsons-disease.aspx\#neil-diamond-stepping-away-from-touring-because-of-parkinsons. Accessed 18 February 2019.

4 https://alz.org/alzheimers-dementia/factsfigures?utm_source = google \&utm $\mathrm{m}$ e di u $\mathrm{m}=\mathrm{p}$ a i d se a r c h \& u t m campaign=google_grants\&utm_content $=$ de mentia\&gclid=Cj0KCQiAzKnjBRDPARIsA KxfTRAzakO7gEGCuZylaj02LBqIlvsgrXrLpmCm MrLqJwyVLbhF7HngR YaAoONEALw_wcB. Accessed 18 February 2019.
5 Reitz C, Mayeux R. Alzheimer disease: epidemiology, diagnostic criteria, risk factors and biomarkers. Biochem Pharmacol. 2014 Apr; 88(4):640-51.

$6 \mathrm{https} / /$ quotesgram.com/dementia-poemsand-quotes/. Accessed 18 February 2019.

7 Mitchell W. Somebody I Used to Know. London: Bloomsbury Publishing; 2018.

8 Rummins T. So, I've Got Parkinson's Disease. Leicester (England): Matador; 2012.

9 Newmark A. Chicken Soup for the Soul: Living with Alzheimer's and other Dementias: 101 stories of Caregiving, Coping and Compassion. Chicken Soup for the Soul, USA; 2014.

10 Andrews J. Dementia: The One-Stop Guide: Practical advice for families, professionals, and people living with dementia and Alzheimer's Disease. London: Profile Books; 2015.
11 Hultquist AM. Can I tell you about Parkinson's Disease? A Guide for Family, Friends and Carers. London: Jessica Kingsley Publishers; 2013.

12 Andrews A. I Have Parkinson's: What Should I Do? An Informative, Practical, Personal Guide to Living Positively with the Many Challenges of Parkinson's Disease. Laguna Beach: Basic Health Publications; 2011.

13 Quarrell OWJ. Huntington's Disease (The Facts). Oxford: Oxford University Press; 2008.

14 https://www.alzheimers.net/quote-we-remember-their-love/. Accessed 18 February 2019.

15 http://justbedementiafriendly.com/dementia-quotes/. Accessed 18 February 2019.

16 Cornish J. The Dementia Handbook: How to Provide Dementia Care at Home. CreateSpace Independent Publishing Platform; 2017. 